\title{
PENERAPAN MODEL PEMBELAJARAN REALISTIC MATHEMATICSEDUCATION (RME) TERHADAP PENINGKATAN KEMAMPUAN REPRESENTASI MATEMATIS SISWA
}

\author{
Cantika N. Yusuf ${ }^{1}$, Yahya Hairun ${ }^{2}$, Ariyanti Jalal ${ }^{3}$ \\ ${ }^{1,2,3}$ Program Studi Pendidikan Matematika, Universitas Khairun
}

\begin{abstract}
ABSTRAK
Penelitian ini didasarkan pada kemampuan representasi matematis siswa yang masih rendah.Penelitian ini bertujuan untuk mengetahui kemampuan representasi matematis siswa setelah diterapkan model pembelajaran Realistic MathematicsEducation pada materi menyelesaikan soal cerita Sistem Persamaan Linear DuaVariabel menggunakan metode grafik dan bagaimana peningkatan kemampuan representasi matematis siswa setelah diterapkan model pembelajaran tersebut.Metode yang digunakan adalah metode deskriptif dengan desain penelitian OneGroup Pretest-Posttest Design.Subjek penelitian adalah siswa kelas VIII B SMPNegeri 7 Kota Ternate. Instrumen yang digunakan: tes hasil belajar, lembar observasi kinerja guru, dan lembar observasi aktivitas siswa, dan dokumentasi. Hasil penelitian ini menunjukkan bahwa kemampuan representasi matematis siswa setelah diterapkan model pembelajaran Realistic Matehmatics Education mengalami peningkatan yang berada pada interpretasi sedang.
\end{abstract}

Kata Kunci: Realistic Mathematics Education, Representasi MatematisMatematis 


\section{PENDAHULUAN}

Representasi merupakan hal yang tidak bisa dipisahkan dalam pembelajaran matematika. Meskipun tidak tercantum secara tersurat dalam tujuan pembelajaran matematika di Indonesia, namun secara tersirat pentingnya representasi tampak pada tujuan pemecahan masalah dan komunikasi matematika, karena untuk menyelesaikan masalah matematis, diperlukan kemampuan membuat model matematika dan menafsirkan solusinya yang merupakan indikator representasi. Menuurt Goldin (Muthmainnah, 2014: 9) representasi merupakan suatu konfigurasi yang bisa merepresentasikan sesuatu yang lain dalam beberapa cara. Kemampuan representasi matematis dalam pembelajaran matematika adalah kemampuan menyajikan atau mengungkapkan masalah matematika dalam bentuk teks tertulis, model matematika, dan visual (gambar, grafik, tabel, diagram). Indikator yang digunakan dalam penelitian ini adalah;

1. Representasi verbal yaitu siswa mampu menyatakan atau menafsirkan denganbahasa sendiri secara tertulis

2. Representasi Simbol yaitu siswa mampu membuat dan menyatakan modelmatematika dari permasalahan yang diberikan dan siswa mampu menyelesaikan masalah dari model matematika yang dibuat

3. Representasi Visual yaitu siswa menggunakan representasi visual (grafik)dalam menyelesaikan masalah.

Berdasarkan data yang peneliti peroleh dari tes kemampuan awal matematis yaitu pada tanggal 11 November 2017 terhadap siswa kelas VIII-B, diperoleh 5 orang tuntas dan 20 orang tidak tuntas, ketuntasan disesuaikan KKM. Seharusnya siswa mampu menyelesaikan soal matematika.Namun kenyataannya dilihat dari hasil jawaban siswa, siswa hanya mampu menyelesaikan butir soal yang memuat indikator memahami konsep, sementara siswa belum mampu menyelesaikan butir soal yang memuat indikator representasi masalah dan memecahkan masalah. 
Kesenjangan antara harapan peneliti dengan kenyataan yang ada inilah yang menjadi masalah yang akan diteliti nantinya. Rendahnya kemampuan representasi matematis siswa dikarenakan pola pembelajaran matematika siswa yang strukturalistik, dimana pengetahuan yang diperoleh siswa hanya terpusat pada guru,tanpa ada inisiatif tersendiri untuk memperoleh pengetahuan sendiri atau dapat disebut latihan mandiri.Sehingga diperlukan model pembelajaran yang membuat siswa berperan aktif dan berusaha memperoleh pengetahuan sendiri seperti dengan menerapkan model pembelajaran Realistic Mathematic Education (RME).RME memiliki karakteristik dimana menurut Treefers (Marzuqoh, 2009: 10) ada beberapa karakteristik dalam model pembelajaran RME diantaranya adalah menggunakan kontekstual, menggunakan model-model (matematisasi), menggunakan konstruksi, menggunakan interaktif, dan keterkaitan.

Keunggulan pembelajaran RME ialah lebih memberikan makna pada peserta didik karena dikaitkan dengan kehidupan dunia nyata.Konteks dunia nyata yang digunakan untuk sumber pembelajaran dapat berperan sebagai penguat kesan (amemory jogger) atau tidak mudah lupa dan peserta didik lebih senang dan lebihtermotivasi karena pembelajaran menggunakan realitas kehidupan (Marzuqoh, 2009: 17).Sementara, Kelemahan-kelemahan dari pembelajaran RME diantaranya; karena sudah terbiasa diberi informasi terlebih dahulu maka peserta didik masih kesulitan dalam menemukan sendiri jawabannya.Dan membutuhkan waktu yang lama terutama bagi peserta didik yang lemah (Marzuqoh, 2009: 17).

\section{METODE}

Penelitian ini merupakan penelitian deskriptif dengan desain penelitian OneGroup Pretest-Posttest Design. Desain penelitiannya yaitu sebelum perlakuan diberikan, terlebih dahulu subjek penelitian diberi pretest (tes awal) dan di akhir pembelajaran subjek penelitian diberi posttest (tes akhir). Subjek penelitian adalah seluruh siswa kelas VIII B SMP Negeri 7 Kota Ternate yang berjumah 25 orang.Variabel dalam penelitian ini adalah kemampuan representasi matematis 
siswa kelas VIII B dengan menerapkan model pembelajaran Realistic MathematicsEducation. Data yang diperoleh dari penelitian ini merupakan data kuantitatif dandata kualitatif.Data kuantitatif adalah hasil tes kemampuan representasi matematis siswa.Data kualitatif berupa observasi dan dokumentasi.Hasil dari data kualitatif tersebut kemudian dikuantitatifkan dan dipersentasekan yang kemudiandiinterpretasikan berdasarkan kriteria keberhasilan. Berikut adalah tabel kriteria taraf keberhasilan tindakan:

Tabel 1

Kriteria Taraf Keberhasilan Tindakan

\begin{tabular}{|c|c|}
\hline Tingkat Keberhasilan & Predikat \\
\hline $86-100 \%$ & Sangat Baik \\
$76-85 \%$ & Baik \\
$60-75 \%$ & Cukup \\
$55-59 \%$ & Kurang \\
$\leq 54 \%$ & Kurang Sekali \\
\hline
\end{tabular}

(Sa'diyah, 2015: 75)

Hasil data kuantitatif menggunakan PAP (Pedoman Acuan Patokan) danRumus N-Gain. Berikut adalah pedoman konversi PAP dan interpretasi N-Gain:

Tabel 2

Pedoman Konversi PAP Skala 5

\begin{tabular}{|l|l|l|}
\hline NO & Presentase & Kriteria \\
\hline 1 & $90 \%-100 \%$ & Sangat baik \\
\hline 2 & $80 \%-89 \%$ & Baik \\
\hline 3 & $65 \%-79 \%$ & Cukup \\
\hline 4 & $55 \%-64 \%$ & Kurang \\
\hline 5 & $0 \%-54 \%$ & Sangat Kurang \\
\hline
\end{tabular}

Thoha (2014: 5)

Tabel 3

Kriteria Rumus N-Gain 
Hake dalam (Alpusari, 2013: 43)

\begin{tabular}{|c|c|}
\hline Interval & Interrestasi \\
\hline$g>0,70$ & Tinggi \\
\hline $0,30<g \leq 0,70$ & Sedang \\
\hline$g \leq 0,30$ & Rendah \\
\hline
\end{tabular}

Hake dalam (Alpusari, 2013: 43)

\section{HASIL PENELITIAN}

Hasil yang diperoleh dari penelitian ini adalah:

1. Hasil observasi pelaksanaan model pembelajaran RME diperoleh presentase $100 \%$ yang interpretasinya sangat baik.

2. Hasil tes awal (pretest) kemampuan representasi matematis dari 22 siswa yang hadir menunjukkan 22 siswa tersebut termasuk dalam kualifikasi kemampuan yang sangat kurang.

3. Hasil tes akhir (postest) kemampuan representasi matematis dari 22 siswa yang hadir diperoleh kualifikasi sangat baik sebanyak 0 siswa (0\%), kualifikasi baik sebanyak 2 siswa (10\%), kualifikasi cukup juga sebanyak 12 siswa (54\%), kualifikasi kurang sebanyak 0 siswa $(0 \%)$, dan yang memperoleh kualifikasi sangat kurang sebanyak 8 siswa $(36 \%)$

4. Peningkatan kemampuan representasi matematis siswa setelah diterapkan model pembelajaran Realistic Mathematics Education dengan perhitungan menggunakan rumus $\mathrm{N}$-gain diperoleh nilai $\mathrm{N}$-gain yaitu 0,50. Berdasarkan kriteria interpretasi $\mathrm{N}$-gain diperoleh kesimpulan bahwa peningkatan kemampuan representasi matematis siswa berada pada interpretasi sedang. 
Data hasil Pretest dan Posttest disajikan dalam tabel berikut:

Tabel 4

Klasifikasi Data Hasil Pretest dan Posttest

\begin{tabular}{|c|c|c|}
\hline Deskripsi & \multicolumn{2}{|c|}{ Tes } \\
\hline & Pretest & Posttest \\
\hline Rata-Rata & 23 & 62 \\
\hline Nilai Minimum & 18 & 23 \\
\hline Nilai Maksimum & 36 & 89 \\
\hline
\end{tabular}

Berdasarkan data pada tabel diatas, data yang diperoleh dari hasil penelitian ini berupa tes tertulis dari kelas VIII B. sebelum melakukan kegiatan belajar dengan model pembelajaran Realistic Mathematics Education, peneliti mengadakan tes awal guna memperoleh data awal kemampuan representasi matematis siswa. Dari tes tersebut diperoleh nilai rata-rata kelas adalah 23 dengan nilai minimum 18 dan maksimum 36.22 siswa yang megikuti pretes tidak tuntas.Hal ini berarti kemampuan representasi matematis siswa rendah. Berikut adalah analisis jawaban pretes salah satu siswa berdasarkan indikator kemampuan representasi matematis:

\section{a. Representasi Verbal}

Representasi verbal yaitu siswa mampu menyatakan atau menafsirkan denganbahasa sendiri secara tertulis. Berikut adalah jawaban siswa untuk indikator tersebut:

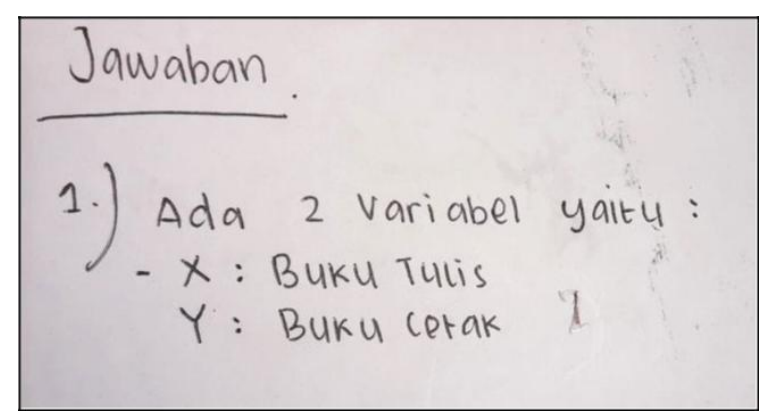




\section{Gambar 1}

Jawaban pretes siswa A indikator ke-1

Jawaban salah satu siswa tersebut benar.Yang artinya dia mampu menyatakan atau menafsirkan dengan bahasa sendiri secara tertulis.

\section{b. Representasi Simbol}

Representasi Simbol yaitu siswa mampu membuat dan menyatakan modelmatematika dari permasalahan yang diberikan dan siswa mampu menyelesaikan masalah dari model matematika yang dibuat. Berikut adalah jawaban siswa untuk indikator tersebut:

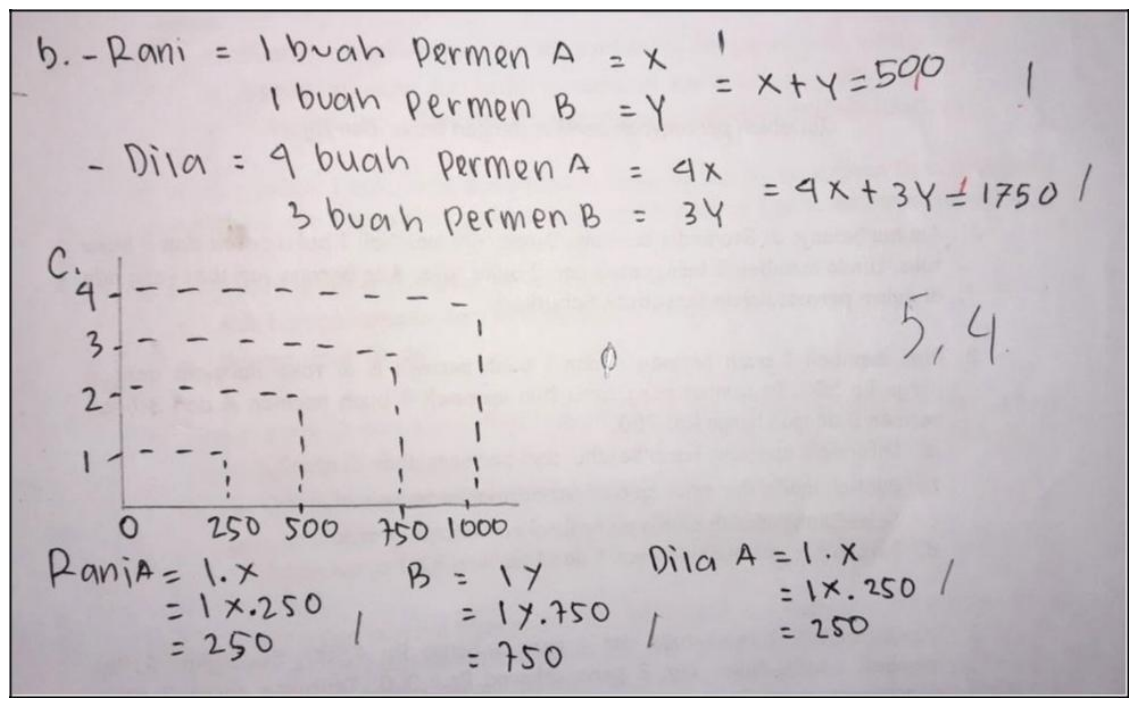

\section{Gambar 2}

Jawaban pretes siswa A indikator ke-2

Gambar 2 menunjukkan siswa mampu membuat model matematika namun belum mampu menyelesaikan masalah menggunakan model matematika tersebut.Seharusnya siswa menggunakan metode grafik dari persamaan yang telah dibuat ke dalam model matematika.

\section{c. Representasi Visual}


Representasi visual yaitu siswa mampu menggunakan grafik untuk menyelesaikan masalah. Berikut adalah jawaban siswa untuk indikator tersebut:

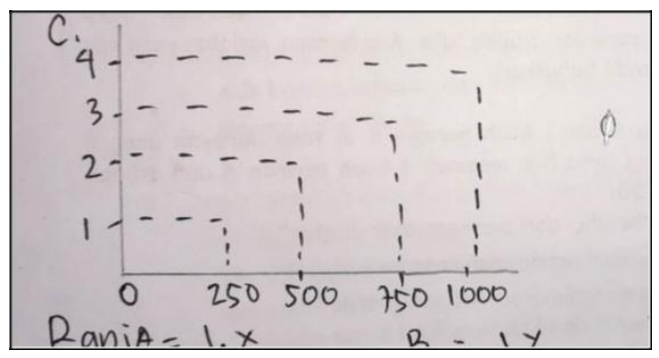

Gambar 3

Jawaban pretes siswa A indikator ke-3

Gambar 3 menunjukkan siswa belum mampu membuat grafik yang benar untuk menyelesaikan masalah tersebut.Seharusnya, siswa harus menentukan titik potong dari masing-masing persamaan yang diketahui terlebih dahulu untuk menggambar grafiknya.

Setelah melakukan tes awal (pretest), pada pertemuan selanjutnya peneliti menerapkan model pembelajaran Realisttic Mathematics Education sesuai RPP, Pada pertemuan berikutnya peneliti memberikan tes akhir (postest) sebagai hasil dari pembelajaran Realisttic Mathematics Education yang diterapkan. Data dari tes akhir tersebut menunjukan bahwa dari 22 siswa yang hadir skor yang diperoleh yaitu nilai minimum 23 dan nilai maksimum 89 dengan nilai rata-rata 62. Hal ini berarti kemampuan representasi matematis siswa ada peningkatan. Berikut adalah analisis jawaban postes siswa yang sama berdasarkan indikator kemampuan representasi matematis:

a. Representasi Verbal

Representasi verbal yaitu siswa mampu menyatakan atau menafsirkan dengan bahasa sendiri secara tertulis. Berikut adalah jawaban siswa untuk indikator tersebut: 


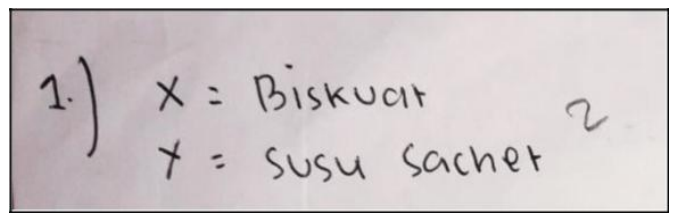

\section{Gambar 4}

Jawaban postes siswa A indikator ke-1

Jawaban salah satu siswa tersebut benar.Yang artinya dia mampu menyatakan atau menafsirkan dengan bahasa sendiri secara tertulis.

\section{b. Representasi Simbol}

Representasi Simbol yaitu siswa mampu membuat dan menyatakan model matematika dari permasalahan yang diberikan dan siswa mampu menyelesaikan masalah dari model matematika yang dibuat. Berikut adalah jawaban siswa untuk indikator tersebut:

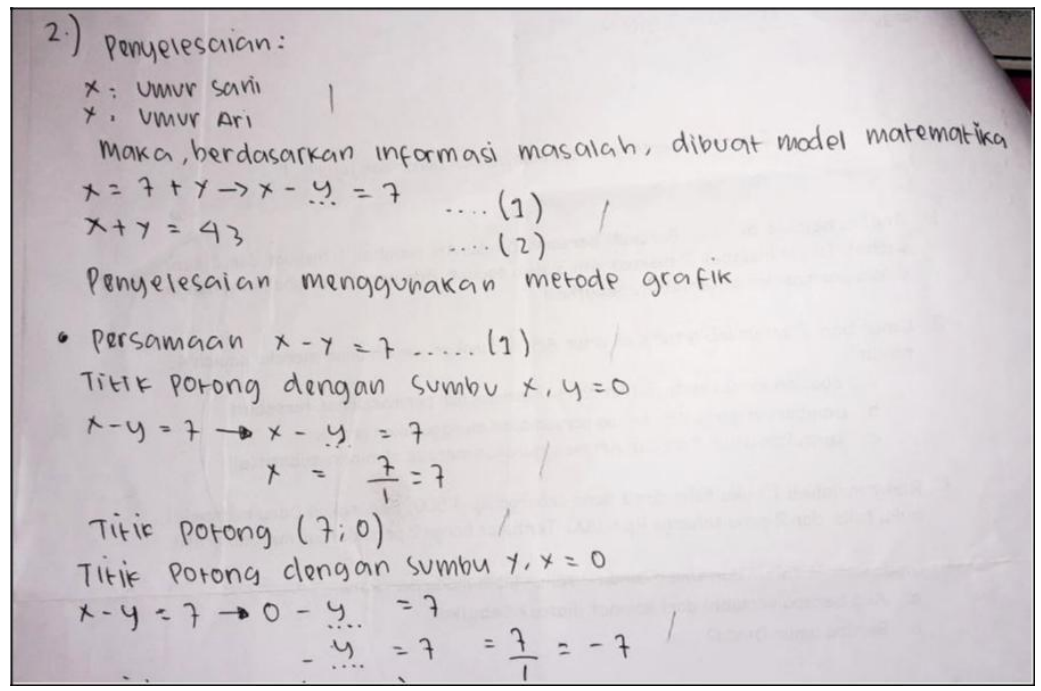

\section{Gambar 5}

Jawaban postes siswa A indikator ke-2

Gambar 5 menunjukkan siswa mampu membuat model matematika dan mampu menyelesaikan masalah menggunakan model matematika tersebut. 


\section{c. Representasi Visual}

Representasi visual yaitu siswa mampu menggunakan grafik untuk menyelesaikan masalah. Berikut adalah jawaban siswa untuk indikator tersebut:

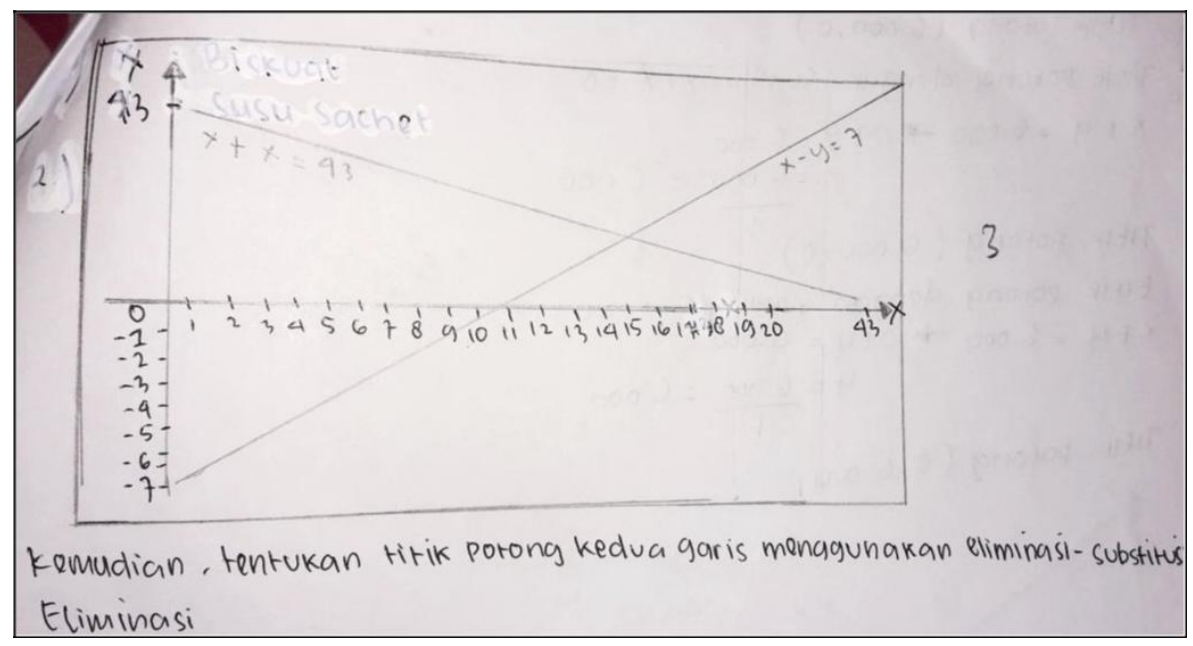

\section{Gambar 6}

Jawaban postes siswa A indikator ke-3

Gambar 6 menunjukkan siswa mampu membuat grafik yang benar untuk menyelesaikan masalah tersebut.Penerapan metode pembelajaran RealisticMathematics Education (RME) ini membuat siswa banyak mengalami perubahan,khususnya pemahaman mereka yang dibantu dengan media LKS.Pemahaman ini mengantarkan mereka pada peningkatan kemampuan representasi matematis siswa. Hal ini dapat dilihat dari hasil rumus N-Gain yang diperoleh yaitu 0,50. Kriteriapeningkatan kemampuan representasi matematis matematis menggunakan $N$-Gain $=0,5$ termasuk pada kriteria sedang. Artinya, peningkatan kemampuan representasi matematis siswa kelas VIII B sedang. 


\section{KESIMPULAN}

Berdasarkan hasil dan pembahasan diatas, dapat disimpulkan bahwa:

1. Hasil penelitian ini berupa tes tertulis dari kelas VIII B. sebelum melakukan kegiatan belajar dengan model pembelajaran Realistic Mathematics Education, peneliti mengadakan tes awal guna memperoleh data awal kemampuan representasi matematis siswa. Dari tes tersebut diperoleh nilai rata-rata kelas adalah 23 dengan nilai minimum 18 dan maksimum 36. Setelah melakukan tes awal (pretest), pada pertemuan selanjutnya peneliti menerapkan model pembelajaran Realisttic Mathematics Education sesuai RPP, Pada pertemuan berikutnya peneliti memberikan tes akhir (postest) sebagai hasil dari pembelajaran Realisttic Mathematics Education yang diterapkan. Data dari tes akhir tersebut menunjukan bahwa dari 22 siswa yang hadir skor yang diperoleh yaitu nilai minimum 23 dan nilai maksimum 89 dengan nilai rata-rata 62.

2. Penerapan metode pembelajaran Realistic Mathematics Education (RME) siswa mengalami perubahan, terutama pemahaman mereka yang dibantu dengan media LKS. Pemahaman ini mengantarkan mereka pada peningkatan kemampuan representasi matematis siswa. Hal ini dapat ditunjukkan dengan nilai $N$-gain dari pretes-postes yaitu 0,5. Artinya peningkatan kemampuan representasi matematis siswa kelas VIII B dalam kategori sedang 


\section{DAFTAR PUSTAKA}

Alpusari. Mahmud. 2013. Analisis Ketrampilan Proses Sains Siswa dalam Pembelajaran IPA SD. E-Jurnal, Universitas Riau.

Marzuqoh, L. 2009. Efektivitas Model Pembelajaran Realistic MathematicEducation terhadap Hasil Belajar Peserta Didik pada Materi Garis dan Sudut Semester II Kelas VII Mts Aswaja Bumijaya Tegal T.A 2007/2008. Skripsi, IAIN Walisongo Semarang: Tidak Diterbitkan.

Muthmainnah.2014. Meningkatkan Kemampuan Representasi Matematis SiswaMelalui Pendekatan Pembelajaran Metaphorical Thinking.Skripsi,Universitas Islam Negeri Syarif Hidayatullah, Jakarta: Tidak Diterbitkan.

Sa'diyah, H. 2015. Penerapan Metode Pembelajaran RME untuk MeningkatkanHasil Belajar Matematika Siswa Kelas III MI Al-Wathaniyah TegalrejoRejotangan .Skripsi, IAIN Tulungagung.

Toha, Habib. 2014. Penerapan Model Pembelajaran Berbasis Masalah untuk Meningkatkan Hasil Belajar Siswa TKJ pada Pelajaran Jaringan Dasar di SMK. Jurnal JJPTE, Vol. 3, No. 4, Hal. 3-9. 